\title{
CHARACTERIZATION OF THE PROTEINS OF HUMAN SYNOVIAL FLUID IN CERTAIN DISEASE STATES ${ }^{1}$
}

\author{
BY K. SCHMID AND MARGARET B. MACNAIR \\ (From the Robert W. Lovett Memorial Laboratories for the Study of Crippling Diseases, Mas- \\ sachusetts General Hospital and Department of Biophysical Chemistry, Harvard \\ Medical School, Boston, Mass.)
}

(Submitted for publication February 20, 1956, accepted April 3, 1956)

In search of the similarities and differences between blood plasma and synovial fluid, on one hand, and normal and pathological joint fluid on the other, it appeared important to investigate systematically the protein components of joint fluid. Investigations of the synovial fluid proteins by electrophoresis have been carried out by several authors (1-4). The identification of these proteins has been initiated $(1,5)$. Fractionation with ammonium sulfate to obtain the albuminglobulin ratio (6) and demonstration of definite properties of certain proteins by immunochemical methods and enzymatic reactions have been reported $(1,5)$.

This publication presents a study on the characterization of the proteins in pathological synovial fluids.

\section{MATERIALS AND METHODS}

The collection of synovial fluid and plasma as well as the procedure for the fractionation of their proteins have been described in a previous publication (7). All fluids were drawn from knee joints of patients with rheumatoid or traumatic arthritis or neuroarthropathy, and were obtained through the courtesy of the clinical staff of the Arthritis Unit. Most of the fluids deposited a precipitate within 20 hours although acid-citrate-dextrose (ACD) solution had been added. Prior to fractionation the joint fluids were treated with hyaluronidase (7).

The electrophoretic and ultracentrifugal analyses were carried out in a Perkin-Elmer electrophoresis apparatus and a Spinco Model $\mathrm{E}$ ultracentrifuge, respectively. Paper electrophoresis was performed essentially according to the method of Grassmann and Hannig $(8,9)$. After being heated at $110^{\circ}$ for 10 minutes, the paper

\footnotetext{
1 This is publication No. 192 of the Robert W. Lovett Memorial Laboratories for the Study of Crippling Diseases, Harvard Medical School, Boston, Massachusetts. Grants in support of these investigations have been received from the Helen Hay Whitney Foundation, New York City, and from the National Institutes of Health, U. S. Public Health Service, A-509. A preliminary report on this work has been published by Karl Schmid and Edith C. Rosa, Federation Proc., 1955, 14, 276.
}

strips were stained with Amidoschwarz 10B.2 The intensity of the color was read in an "Elphor" densitometer. ${ }^{2}$ The relative percentage of the separated proteins was determined planimetrically from the curve obtained by plotting the optical density as a function of distance on the paper strip. A correction factor of 1.5 was applied for orosomucoid $(10,11)$, of which the polypeptide moiety was 66 per cent.

Immunochemical methods: For the immunoelectrophoresis described by Grabar and Williams (12) a plate glass $(25 \times 25 \mathrm{~cm}$.) was used as support. Plasticin $(1.2 \mathrm{~cm}$. high) was mounted approximately $2.5 \mathrm{~cm}$. from the edges of the plate. The plate glass was carefully warmed and $20 \mathrm{ml}$. of $\mathrm{pH} 8.6, \mathrm{r} / 20.07$ borate buffer containing 2 per cent agar were added so as to obtain an even layer, (to 1 volume of 4 per cent aqueous agar solution, Bacto Agar, Difco, extracted with distilled water for 24 hours prior to heating, 1 volume of borate buffer was added; the borate buffer consisted of 1 part of $0.07 \mathrm{M} \mathrm{Na}_{2} \mathrm{~B}_{4} \mathrm{O}_{\text {r }}$ and 2 parts $0.07 \mathrm{M} \mathrm{H}_{8} \mathrm{BO}_{3}$; borate buffer was preferred because of its inhibitory effect on the growth of molds). After cooling to room temperature, 6 plastic pieces $(0.6 \times$ $1.2 \times 15 \mathrm{~cm}$.) were arranged on the agar parallel to each other and to one edge of the plate. Their ends were $5 \mathrm{~cm}$. away from the next edge, thus forming 5 spaces of $3 \mathrm{~cm}$. width and $15 \mathrm{~cm}$. length. Next, $200 \mathrm{ml}$. of the same agar solution were added giving a thickness of 0.8 to $1.0 \mathrm{~cm}$. After the plate had again been cooled to room temperature, the plastic pieces were loosened with a spatula and carefully removed. The resulting 6 troughs were used after electrophoresis to receive the antiserum. In the center of each section $(3 \times 15 \mathrm{~cm}$.) which was separated by the troughs, a small reservoir $(1.2 \mathrm{~cm}$. long, $0.25 \mathrm{~cm}$. wide and $0.9 \mathrm{~cm}$. deep) was cut out. The main axis of the reservoirs was perpendicular to the troughs and one or two drops of liquid borate-agar was added to each to seal any breaks. Then, the protein solutions (serum, synovial fluid digested with hyaluronidase, 4 per cent human serum albumin, and 1.2 per cent human $\gamma$-globulin), previously dialyzed against the same borate buffer, were mixed at $52^{\circ} \mathrm{C}$ with an equal volume of 4 per cent aqueous agar solution. The individual reservoirs were filled exactly to the level with one of the protein solutions. The agar plate was then placed in the electrophoresis box (outer dimensions: $38 \times 26 \times 12 \mathrm{~cm}$; ; buffer chambers $26 \times 6.7 \times 3.4 \mathrm{~cm}$; center compartment $26 \times 26 \times$ 5.5) and transferred to a $2^{\circ} \mathrm{C}$ room. Four layers of

\footnotetext{
2 Bender and Hobein, Munich, Germany.
} 


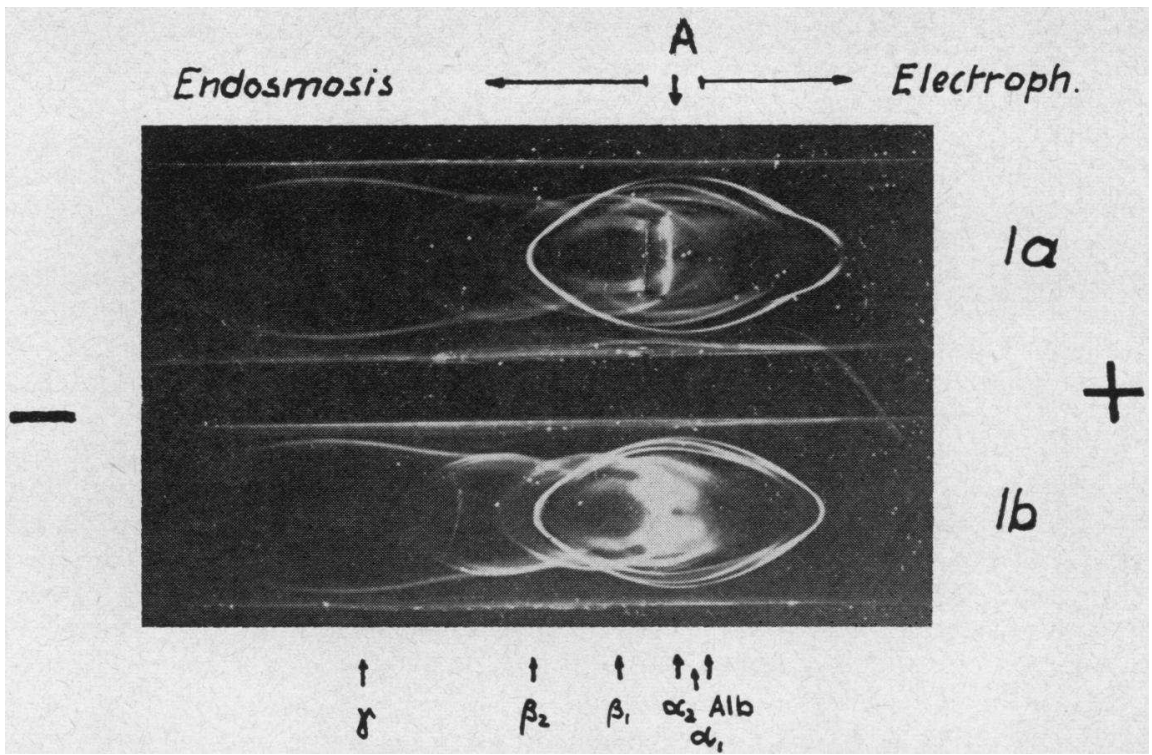

Fig. 1. Immunoelectrophoresis of Traumatic Synovial Fluid (a) and Serum (b) FROM THE SAME INDIVIdUAL

Joint fluid had been treated with hyaluronidase prior to the experiment. A indicates the position of application. Electrophoresis in borate buffer, $\mathrm{pH} 8.6, \mathrm{r} / 2$ 0.07, containing 2 per cent agar, for 17 hours at $180 \mathrm{~V}$ and $40 \mathrm{~mA}$. The arrow "Electroph." indicates the direction of the electrophoretic movement of the proteins, and the arrow "Endosmosis" indicates the direction of the electroendosmosis. After the electrophoresis was completed, the troughs between the agar sections were filled with horse serum against human serum. Therefore, the precipitin zones formed symmetrical patterns. The positions of albumin and $\gamma$-globulin were found by applying these proteins as references on adjoining sections. The precipitin zones of synovial fluid (a) appeared less intense than those of the serum because of its lower protein concentration. The line corresponding to albumin, however, was very distinct due to the relatively high albumin concentration in this joint fluid.

Whatman No. 1 paper $(24 \mathrm{~cm}$. wide) soaked in the borate buffer were used as electric connection between the ends of the agar plate and the adjoining borate buffer reservoirs. The buffer chambers, in turn, were again connected to holes filled with glass wool with a second set of buffer chambers in which the electrodes were placed. The electrodes were made by winding $120 \mathrm{~cm}$. of stainless steel wire $(0.05 \mathrm{~cm}$.) around a glass tube with diameter of $1.5 \mathrm{~cm}$. To secure an even level of the buffer in all 4 compartments, the two inner reservoirs were connected with each other by a thin rubber tubing. After half an hour of temperature equilibration, 180 volts were applied giving a current of $40 \mathrm{~mA}$. The electrophoresis was continued for 17 hours. Owing to strong electroendosmosis, acting in the direction opposite to the electrophoretic movement, albumin remained almost exactly at the position of application, and $\boldsymbol{\gamma}$-globulin appeared to have moved against the direction indicated by the electrophoretic mobility (Figure 1). Between the albumin and $\gamma$-globulin, the $\alpha_{1^{-}}, \alpha_{2^{-}}, \beta_{1^{-}}$, and $\beta_{2}$-globulins were distributed according to their electrophoretic mobilities. During electrophoresis, diffusion occurred so that each group of globulins would appear as a band, broader than the reservoir where the protein solution was originally applied. Under these circumstances, the albumin, $\alpha_{1}-$ and $\alpha_{2}$-globulin did not appear to be well separated. After electrophoresis, the plate was brought to room temperature, the troughs filled with the antiserum, and the system kept in an air-tight box to prevent dehydration. The proteins of the antiserum diffused into the two adjoining agar sections at approximately the same rate, at each point along a line parallel to the troughs. The proteins of the analysis, now separated according to their electrophoretic mobilities, diffused further toward the troughs, as well as in the direction of the main axis of the agar sections. At the point where the corresponding antibodies and antigens met (point of equivalence), a complex of these two components was formed and precipitated as lines. Such complexes are known to be soluble in excess of either antibody or antigen. Thus, depending on their concentration, different amounts were transported by diffusion toward the precipitin zones, which were dissolved, and new ones formed (assuming that the precipitin zones did not present an obstacle to diffusion). Consequently, one observed that these zones moved either toward or away from the troughs. The precipitin zones 
appeared as elliptical curves because the concentration of the antigens varied from zero over a maximum to zero when observed along a line parallel to the troughs. For the exact interpretation of the precipitate lines see references 12-14. After 6 hour's, the first faint line corresponding to albumin became visible, and within 6 days all lines had formed. The antiserum which diffused into the agar sections cleared the turbidity of the agar plate and facilitated the taking of pictures. The number of precipitin zones indicated the minimal number of antigen components. Using this particular antiserum, 12 lines were observed. The pictures were taken in the following way: A beam of light illuminating the agar section with the precipitin lines, was projected from an angle beneath the plate. In this way the precipitate lines showed up against the dark background. Care was taken to avoid dust. The agar plate was washed with soft paper previously soaked in saline.

For the Ouchterlony test (15), $10 \mathrm{ml}$. of the above mentioned agar-borate solution was poured into each petri dish and allowed to gel. After prolonged cooling, rubber-serum stoppers $(1.4 \mathrm{~cm}$. outer diameter $)$ perforated with 21 gauge hypodermic needles were placed on each plate, one in the center and usually four more at distances of $1.6 \mathrm{~cm}$. from the center and at equal distance from each other. Next, 25 to $30 \mathrm{ml}$. more agar solution was added. When thoroughly cooled, the stoppers were removed and 2 to 3 drops of agar were added to each reservoir to seal off any breaks. In our experiments, the antiserum was placed in the center reservoir and the test solutions in the others. The formation of the zones is governed by the same principle as described in the method of Grabar. The exact interpretation, particularly of the complications, has been further studied by Burtin (13) and Wilson and Pringle (14). It was concluded from the precipitin zones which formed closed systems (fusion of the precipitate lines), that the corresponding proteins were identical.

Furthermore, the technique described by Oudin (16) was applied to certain protein fractions to identify the $\gamma$-globulins. For the titration of the antistreptolysin- $O$ content and for the determination of the diphtheria antitoxin content (rabbit skin test), the standard methods $(17,18)$ were used.

Ceruloplasmin (19) was determined as follows: Fraction III was dialyzed at $2^{\circ} \mathrm{C}$ against distilled water for 14 hours to remove the ethanol. Insoluble material was centrifuged off. The optical density of the supernatant solution was read against water between 580 and $630 \mathrm{~m} \mu$ at intervals of $10 \mathrm{~m} \mu$, in a Beckman DU spectrophotometer using a $1-\mathrm{cm}$. cell. An aliquot of $3.0 \mathrm{ml}$. of the supernatant solution was mixed with $0.2 \mathrm{ml}$. of a 1 per cent $\mathrm{KCN}$ solution, and its optical density read in the same way after standing for 5 hours at room temperature. For the calculation of the percentage of ceruloplasmin, the difference in optical densities at $610 \mathrm{~m} \mu$, representing the maximal absorption of this protein in the visible spectrum, was divided by the extinction coefficient of $0.68\left(=\mathrm{E}_{1 \mathrm{~cm}}^{1 \%}\right)$. Appropriate corrections for dilution occurring during fractionation, dialysis, and addition of the
$\mathrm{KCN}$ solution were applied. The corresponding fraction derived-from normal human plasma was measured simultaneously. This procedure can obviously be simplified, when sufficient material is available, by reading the dialyzed and centrifuged Fraction III against an aliquot of the same solution which had previously been treated with $\mathrm{KCN}$.

Lipoproteins expressed as cholesterol were measured by the method of Bloor, Pelkan, and Allen (20).

The $\beta_{1}$-metal-combining protein determinations $(21,22)$ were carried out as follows : $500 \mathrm{ml}$. of citrate barbiturate buffer, $\mathrm{pH} 8.6, \mathrm{\Gamma} / 2$ 0.1, commonly employed in electrophoresis, were added to $37.5 \mathrm{ml}$. of acetate buffer, $\mathrm{pH}$ 4.0, $\Gamma / 20.1$, to obtain a $\mathrm{pH}$ of 7.4. After standing over night in the cold room, the precipitated barbituric acid was separated, and the supernatant solution was mixed with $20 \mathrm{ml}$. of freshly prepared 20 per cent $\mathrm{Fe}\left(\mathrm{NH}_{4}\right)_{2}$ $\left(\mathrm{SO}_{4}\right)_{2}$-solution. Aliquots of Fractions IV and $\mathrm{V}$ were dialyzed for two days against this buffer. The intensity of the developed pink color $\left(E_{1 \%}^{1 \%}=0.57\right)$ was measured at $465 \mathrm{~m} \mu$, part of the same protein solutions acidified with $0.1 \mathrm{ml}$. of acetic acid per ml. being used as a blank.

Albumin was measured by the method of Rutstein, Ingenito, and Reynolds (23) which involved the determination of the capacity of albumin to bind 2-(4'-hydroxybenzeneazo) benzoic acid (HBABA).

\section{RESULTS}

For the characterization of the synovial fluid proteins, two fundamentally different approaches were chosen. First, the proteins were identified by precipitin reactions after separation by electrophoresis in agar (method of Grabar). Second, the proteins were separated into six fractions by means of solubility differences ( 7 ), and were then characterized by chemical and physico-chemical methods and by the measurement of definite properties of proteins known to occur in blood plasma. In contrast to the first method that permits qualitative measurements only, the second makes possible qualitative and quantitative determinations.

\section{Characterization of the synovial fluid proteins by immunoelectrophoresis}

Synovial fluids from patients with rheumatoid arthritis or knee injuries together with the plasma from the same individuals were investigated simultaneously. The results obtained were consistent: The characteristics, number and distribution of precipitin zones were the same for each set of fluids, and suggested that the proteins of plasma also occur in synovial fluid as judged by these characteristic tests. The precipitin zones were 
grouped according to the electrophoretic mobilities of albumin, $\alpha_{1^{-}}, \alpha_{2^{-}}, \beta_{1^{-}}, \beta_{2}$, and $\gamma$-globulin, but only the zones corresponding to albumin and $\gamma$-globulin were identified. It is important, however, to note that the immunoelectrophoretic patterns obtained from joint fluid and plasma of the same patient were identical. A typical experiment is illustrated in Figure 1.

2. Characterization of the synovial fluid proteins after separation by the low temperature-low salt-ethanol procedure

Joint fluids and plasma from the same individuals were fractionated simultaneously. A proper comparison could thus be obtained as well as a test of the reliability of the method, for which the results from normal human plasma were used as references ( 7$)$. Two characteristic experiments are reported as examples.

a. Synovial fluid from a patient with rheumatoid arthritis: Synovial fluid obtained from a patient (W. W. 745536) with rheumatoid arthritis was centrifuged at approximately 12,000 r.p.m. for one hour, yielding a straw-yellow, viscous fluid. Since fractionation was not carried out immediately, the fluid was kept at $-30^{\circ}$ for two months. After being thawed the clear fluid was digested with hyaluronidase. A clot which formed within 14 hours was centrifuged off. ACD-plasma from the same individual was also kept at $-30^{\circ}$ for the same time. The electrophoretic distribution of the proteins of the original fluid and plasma was identical.

For the fractionation, $28 \mathrm{ml}$. of ACD-synovial fluid and $20 \mathrm{ml}$. of ACD-plasma were used so that each contained approximately equal amounts of protein. Essentially the same results (Table I) were obtained from both joint fluid and plasma: The protein content of each of the six fractions (except Fraction I of synovial fluid because of its previous clotting), the content of protein-bound hexose, the distribution of the cholesterol, the electrophoretic distribution and the mobilities of the proteins and the distribution in the ultracentrifuge, as well as the calculated sedimentation constants, were within experimental errors found to be alike for both sets of fractions. ${ }^{3}$ The percentages of

\footnotetext{
3 These sedimentation constants were identical to those reported for the corresponding fractions from normal human plasma.
}

$\gamma$-globulin in Fraction I and III were very similar to those of the corresponding fractions from normal human plasma ( 7$)$.

In addition to these investigations, during which the proteins were studied from the point of view of general characteristics, except for the cholesterol and in part the carbohydrate content, experiments were carried out for the determination of definite properties of certain protein components known to occur in plasma. Again, these experiments were performed simultaneously with the fractions from both synovial fluid and plasma. The clotting of Fraction $I$ indicated the presence of fibrinogen. The clear supernatant solution was kept at $+2^{\circ} \mathrm{C}$ for 20 hours resulting in the formation of a precipitate. The solubility of the precipitated material at room temperature proved the presence of "cold-insoluble globulin" (24). Fraction $I I$, in which the $\gamma$-globulins were concentrated, was analyzed for specific antibodies. The antistreptolysin-O content, of which normal human plasma contains between 50 and 250 standard units per ml. amounted to $45 \mathrm{U}$ per $\mathrm{ml}$. of ACD-synovial fluid. However, the protein concentration of the latter fluid was only 5.7 per cent. The antistreptolysin-O titre in both Fractions II were almost equal. Diphtheria antitoxin showed the same distribution, namely, the activity of the proteins in each of the two Fractions II was approximately half of the total. The presence of ceruloplasmin precipitated in Fractions III was evidenced by its blue color after incubation of an aliquot for 10 minutes at $70^{\circ} \mathrm{C}$. Fraction III of synovial fluid and of plasma exhibited the same isoagglutinin titre. The content of the $\beta_{1}$ - and $\alpha_{1}$-lipoproteins, judged by the cholesterol content of Fraction III and Fraction $I V$, was almost equal for both fluids. Fraction IV contained approximately 20 per cent of the $\alpha_{2}$-globulins ; the rest had previously been precipitated in Fraction III. The estimation of the $\alpha_{2}$-globulins in Fraction III from the electrophoretic pattern might be erroneous owing to the change in the mobility of the $\beta_{1}$-lipoproteins due to autoxidation (25). The amount of $\beta_{1}$-metal-binding protein concentrated in Fraction $V$ was the same for both fluids, amounting to 3 per cent, while Fraction IV was free of this component. The albumin of Fraction V, which was marked by a distinct yellow color and its low content of bound hexose, exhibited the same capacity to bind 


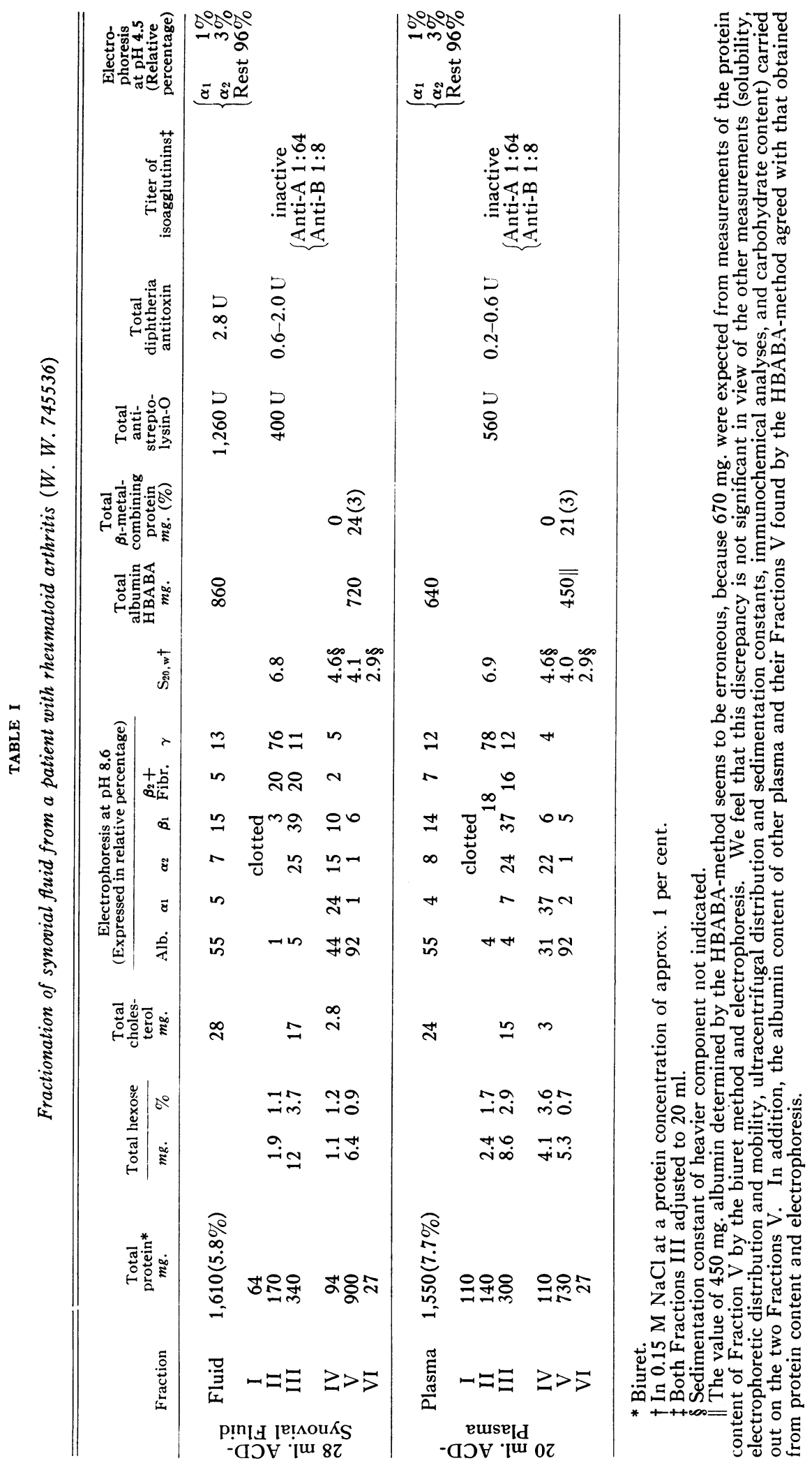




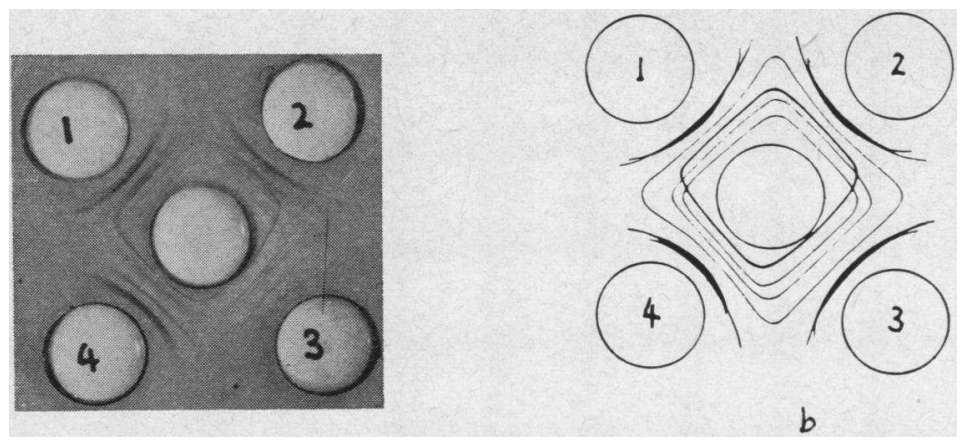

Fig. 2. Ouchterlony Plate (2a) of Fraction III Obtained from Arthritic Synovial Fluid

Figure $2 \mathrm{~b}$ represents a sketch of Figure 2a. Reservoir 1 contained Fraction III of this synovial fluid, reservoir 2 Fraction III of the same patient's plasma, reservoir 3 normal human plasma, reservoir 4 Fraction II + III of normal human plasma and center reservoir horse serum against human serum.

HBABA as normal human serum albumin is known to have (23). The presence of $\alpha_{1}$ - and $\alpha_{2}$-glycoproteins in Fraction $V I$ was shown by their low sedimentation constant. The acid isoelectric points (10), indicated by electrophoresis of the original fluids at $\mathrm{pH} 4.5$, conform with this view.

Fractions II, III, IV, and V were also investigated for identity of the proteins by the method of Ouchterlony. The corresponding fractions of synovial fluid and plasma from the same patient as well as that of normal human plasma were put on the same plate. The concavities for these four solutions were arranged on the plate at equal distances from the center one in which horse serum active against human serum was placed. It was again concluded that most of the proteins in the corresponding fractions were identical, as judged by the precipitin zones which formed closed systems (Figure 2a). The $\gamma$-globulin content of Fractions III and Fractions IV, amounting to a small percentage of the total as judged by electrophoretic analysis, was identified with a specific rabbit serum against human $\gamma$-globulin with use of the technique of Oudin.

For the experiment described in section 2a, a patient with rheumatoid arthritis was chosen who showed severe knee involvement, and whose synovial fluid and plasma revealed essentially the same patterns upon electrophoresis. During this study, joint fluids from six other patients with rheumatoid arthritis or neuroarthropathy were also fractionated. They were characterized by their low content of the $\alpha_{2}$-globulins and increased content of $\gamma$-globulins, compared with the plasma of the same individuals (26). The results obtained from investigating the protein fractions of these joint fluids were essentially the same as those reported in the previous experiment. If the $\gamma$-globulin content was 20 per cent or higher, only part of it could be extracted from Fraction II + III into Fraction II.

b. Synovial fluid from a patient with traumatic arthritis: Synovial fluid and serum obtained from a healthy individual (RBJE) 2 days after an injury to his knee were centrifuged and stored at $-30^{\circ} \mathrm{C}$ until fractionation was carried out. Since the volume of the serum was too small to perform a complete analysis, particularly fractionation, plasma from a different healthy individual was fractionated simultaneously. Prior to the fractionation, the synovial fluid was digested with hyaluronidase. The fluid clotted within 20 hours. The electrophoretic distribution of the proteins of the original synovial fluid, distinguished by the high content of albumin and $\gamma$-globulin and low content of $\alpha_{2}$-globulin, is typical of traumatic joint fluid (26). The electrophoretic pattern of the serum was normal.

The characterization of the synovial fluid proteins after fractionation showed the following results (Table II): The relative amount of protein in the six fractions was essentially the same as that reported for normal human plasma. The low protein content of Fraction I was due to the decreased concentration of fibrinogen, and that 


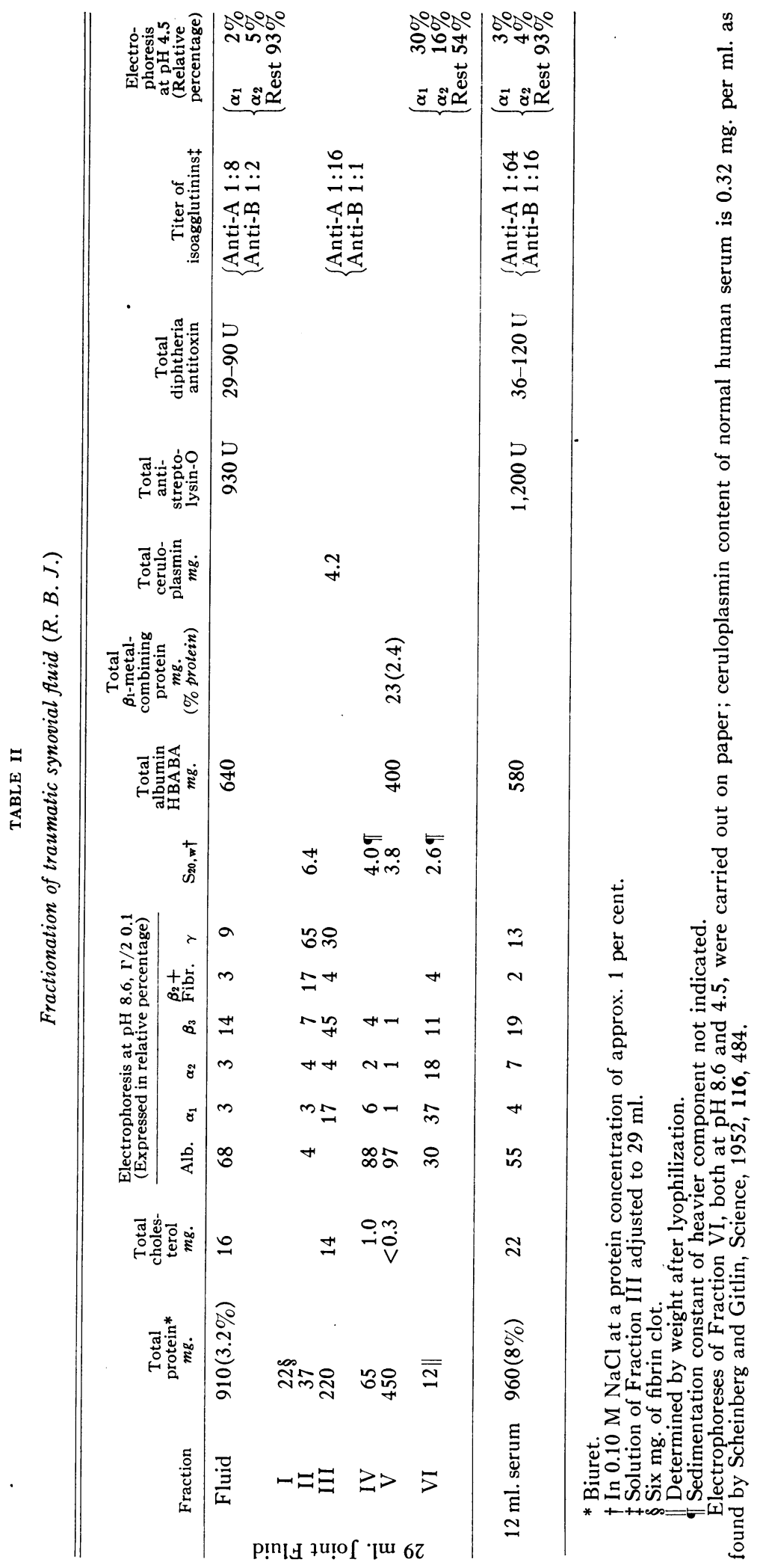




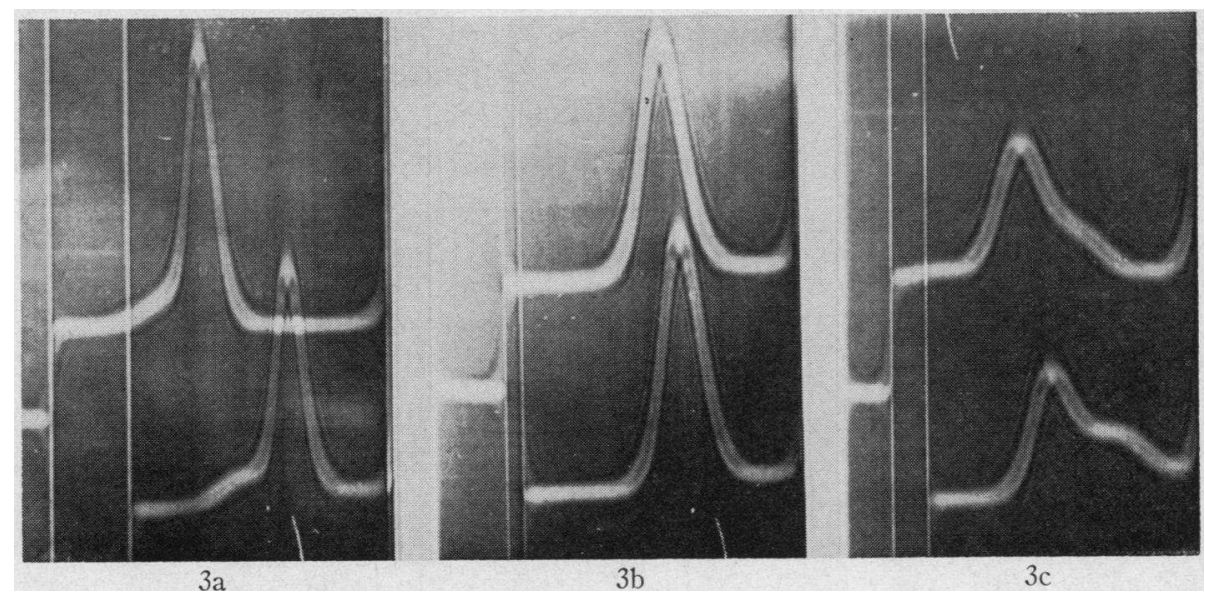

Fig. 3. Ultracentrifugal Analyses of Protein Fractions from Traumatic Joint FLUID

The analyses were carried out under the following conditions: $0.15 \mathrm{M} \mathrm{NaCl}, 56100$ r.p.m., temperature $19^{\circ} \mathrm{C}$ to $20^{\circ} \mathrm{C}$, protein concentration approximately 1 per cent, direction of sedimentation from left to right. Each picture shows two curves; two samples were run simultaneously by means of a wedge window cell. The upper curve, the meniscus of which is displaced to left due to slightly larger volume of the sample, is that of the sample in the wedge window. The bottom curves represent the synovial fluid fractions and the top curves the corresponding fractions of normal human plasma. Figure 3a, Fraction II ( $\gamma$-globulin) ; 73 minutes, wire angle $50^{\circ}$; Figure $3 \mathrm{~b}$, Fraction V (albumin), 116 minutes, wire angle $50^{\circ}$; Figure 3c, Fraction VI (glycoproteins), 137 minutes, wire angle $50^{\circ}$.

of Fraction IV perhaps due to the low $\alpha_{2}$-globulin concentration in the original fluid. The electrophoretic distribution and the mobilities of the proteins of the six fractions as well as their ultracentrifugal distribution (Figure 3 ) and sedimentation constants were essentially identical with those reported for normal human plasma (27).

Again, additional specific tests were carried out to prove the existence in traumatic joint fluid of protein components present in blood plasma. Fibrinogen was detected in the synovial fluid and in Fraction I by the formation of a clot. Cold insoluble globulin concentrated in Fraction I was recognized by its extreme insolubility at $+2^{\circ} \mathrm{C}$ and its relatively high solubility at room temperature. The titres of diphtheria antitoxin and antistreptolysin- $O$ of both synovial fluid and serum, corrected for protein concentration, were found to be comparable to those reported for average normal human plasma. The content of ceruloplasmin, expressed as percentage of the total protein concentration, ranged within the values reported for normal human plasma. The total cholesterol content was approximately one-half that of normal human plasma, if calculated on the basis of the total amount of protein. It is important to point out that the cholesterol content of Fractions IV and $\mathrm{V}$, representing the $\alpha_{1}$-lipoproteins, was about 12 per cent of the total as compared with 25 per cent of the same fractions of normal human plasma. Similar observations were made by Noble, Boucek, and Kao (28) in their study on the lipoproteins of connective tissue. Further investigation by the flotation technique might yield more information about the distribution of the lipoproteins. The content of $\beta_{1}$-metal-combining protein was 6 per cent of the protein in Fraction $\mathrm{V}$ or 3 per cent of the total protein, which was equal to the value reported for normal human plasma (29). The content of albumin, measured by its capacity to bind HBABA, was essentially that found by electrophoresis. The presence of orosomucoid and other glycoproteins of low molecular weights and acid isoelectric points was proven by paper electrophoresis of Fraction VI (Figure 4) and by free electrophoresis of the original joint fluid, both at $\mathrm{pH} 4.5$. Furthermore, the high content of protein-bound hexose of this 
fractiol, amounting to 10 per cent, equaled the corresponding value of Fraction VI of normal human plasma. The identity of the proteins in traumatic synovial fluid was further confirmed by immunochemical analyses using the Ouchterlony technique described in section 1 .

\section{DISCUSSION}

For the characterization of a protein, it has become clear that the results obtained from one method only can never establish its identity. Because of the complexity of the protein molecule, a series of methods based on different principles should be included in such a study.

For the characterization of the synovial fluid proteins, the proteins of joint fluid were separated from each other by means of differences in their electrostatic charges as well as in their solubilities. The method of Grabar combined electrophoresis with immunochemical reactions, of which the specificity is extremely high. The procedure for the separation of the proteins into solubility groups, referred to as fractions in Tables I and II, made possible the recovery and further investigation of the proteins. The conditions of precipitation of the proteins represent a precise measure for their solubilities, which are some of their characteristics.

In characterizing the synovial fluid proteins, it was found that the proteins of the corresponding fractions, derived from synovial fluid and plasma of the same individual, exhibited the same solubility properties, the same electrophoretic distribution and mobilities of the respective components, and the same sedimentation constants. Yet, the possibility existed that these proteins were not identical. In order to exclude such a possibility, further independent methods were employed which allowed the measurement of very distinct properties of the proteins such as titres of isoagglutinin, diphtheria antitoxin, and antistreptolysin-O, reaction of ceruloplasmin with cyanide ions, and ionbinding capacity of albumin and $\beta_{1}$-metal-combining protein. It was concluded from the results of the different methods used that, for the most part, the synovial fluid proteins are identical

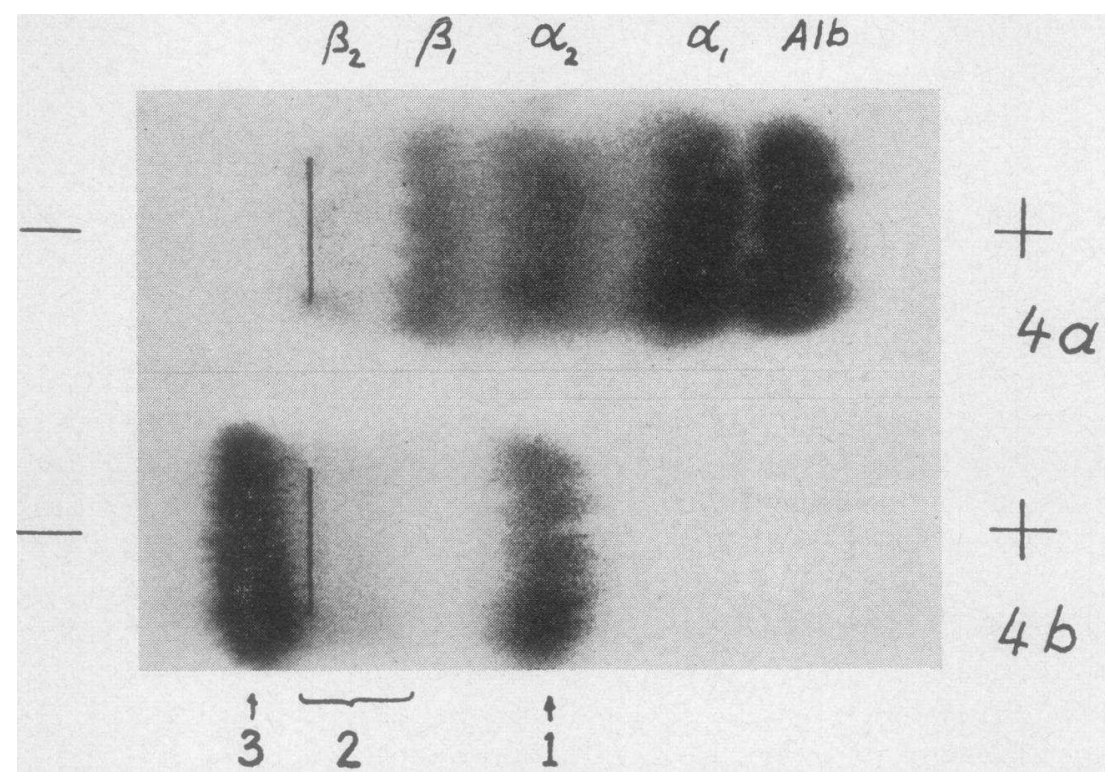

Fig. 4. Paper Electrophoresis of Fraction Vi, Derived from Traumatic Joint Fluid, in Diethyl-Barbiturate Buffer $\mathrm{pH} 8.6, \mathrm{~T} / 20.1$ (4a) and in Acetate Buffer pH 4.5, $\mathrm{\Gamma} / 20.1$ (4b)

The dark lines indicate the position of application. Staining with Amidoschwarz 10B. Area 1 in Figure $4 \mathrm{~b}$ is representative of orosomucoid identical with $\alpha_{1}$-globulin in Figure $4 \mathrm{a}$; area 2 is identical with most of the $\alpha_{2}$-globulin in Figure $4 \mathrm{a}$, and area 3 representing the proteins which were positively charged at $\mathrm{pH} 4.5$, includes albumin, $\beta$-globulin, and a minute part of the $\alpha_{2}$-globulin. 
with those of plasma. It is emphasized that the findings described do not relate to normal synovial fluid which may present a different pattern. The existence of special protein components present solely in synovial fluid is not excluded.

Although the synovial fluid proteins exhibited the same characteristics as the plasma proteins, the following differences were found: First, the differences in total protein concentration and in the relative content, especially of albumin, $\alpha_{2}-$ and $\gamma$-globulins, reported earlier (26), were confirmed. Second, the ratio of $\beta_{1}$ - to $\alpha_{1}$-lipoprotein, measured as cholesterol, appeared higher than that of normal human plasma.

It should be pointed out that it is a difficult task to establish the identity of two proteins (30). The results obtained from these investigations led obviously to the question of the fine structure of the "identical" proteins, in other words, as to whether or not one individual always synthesizes a certain protein by exactly the same process.

\section{SUMMARY}

The proteins of synovial fluid from patients with rheumatoid arthritis, neuroarthropathy, or traumatic injury have been characterized. They are identical with those of plasma as judged by the results obtained from several different methods including electrophoresis, ultracentrifugal analyses, separation by solubility, immunochemical methods, and ion-binding measurements. The following proteins were identified: Fibrinogen, cold insoluble globulin, diphtheria antitoxin, antistreptolysin- $\mathrm{O}$, isoagglutinins, ceruloplasmin, $\beta_{1}$-metalcombining protein, $\alpha_{1}$ - and $\beta_{1}$-lipoproteins. Albumin, $\gamma$-globulin, and glycoproteins of low molecular weights and acid isoelectric points were isolated. Known differences between synovial fluid and plasma were confirmed.

\section{ACKNOWLEDGMENTS}

The authors would like to express their appreciation to Dr. Marian W. Ropes and the other members of the clinical staff of the Lovett Memorial Laboratories through whose effort the synovial fluid was made available. Our thanks are also due to Dr. James Heyl of Exeter, N.H., for providing the traumatic joint fluids. We are particularly indebted to Dr. Robert Berg for the gift of horse serum against human serum, to Miss Jessy Hendry, New York State Department of Health,
Albany, N. Y., for the gift of horse sera against human $\gamma$-globulin and albumin, respectively, and to Dr. Harry Bowen of the Division of Biologic Laboratories, Massachusetts Department of Health, for the antistreptolysin and diphtheria antitoxin determinations. We should also like to thank Drs. D. Gitlin and H. Habich, the Children's Medical Center, for the introduction in the immunochemical methods. The expert assistance of Mrs. Juliet C. McGlynn and Miss Annemarie Ulrich who performed the electrophoretic and ultracentrifugal analyses, is gratefully acknowledged.

\section{Addendum}

The designation "orosomucoid" is used for the human glycoprotein previously named "MP-1" by Winzler (11) and "acid glycoprotein" by Schmid (10).

\section{REFERENCES}

1. Ropes, M. W., and Bauer, W., Synovial Fluid Changes in Joint Diseases. Published for the Commonwealth Fund by Harvard University Press, Cambridge, 1953.

2. Schürch, O., Violier, G., and Süllmann, H., Elektrophoretische Untersuchung von Kniegelenkergüssen. Schweiz. med. Wchnschr., 1950, 80, 711.

3. Olhagen, B., The protein pattern of joint exudates. Acta orthop. Scandinav., 1950, 20, 114.

4. Schmid, J., Neumayr, A., and Ferstl, A., Uber die Hämagglutination in Gelenkpunktaten. Wien. Ztschr. inn. Med., 1953, 34, 74.

5. Robinson, W. D., Rheumatism and arthritis. Review of American and English literature of recent years. Ann. Int. Med., 1953, 39, 498.

6. Gaebler, O. H., Beher, W. T., Sigler, J. W., and Galpin, R. R., Reproducibility and validity of sodium sulfate fractionation of proteins in plasma and knee joint fluid. Clin. Chem., 1955, 1, 105.

7. Schmid, K., Rosa, E. C., and MacNair, M. B., Fractionation of the proteins of human synovial fluid and plasma. J. Biol. Chem., 1956, 219, 769.

8. Grassmann, W., and Hannig, K., Ein quantitatives Verfahren zur Analyse der Serumproteine durch Papierelektrophorese. Hoppe-Seyler's Ztschr. f. physiol. Chem., 1952, 290, 1.

9. Herbst, F. S. M., Lever, W. F., Lyons, M. E., and Hurley, N. A., Effects of heparin on the lipoproteins in hyperlipemia. An electrophoretic study of the serum alpha and beta lipoproteins after their separation by fractionation of the plasma proteins or ultracentrifugal flotation. J. Clin. Invest., 1955, 34,581 .

10. Schmid, K., Preparation and properties of serum and plasma proteins. XXIX. Separation from human plasma of polysaccharides, peptides and proteins of low molecular weight. Crystallization of an acid glycoprotein. J. Am. Chem. Soc., 1953, 75, 60.

11. Winzler, R. J., Determination of serum glycoproteins in Methods of Biochemical Analysis. D. 
Glick, Ed., New York, Interscience Publishers, Inc., 1955, Vol. II, p. 279.

12. Grabar, P., and Williams, C. A., Jr., Méthode immuno-électrophorétique d'analyse de mélanges de substances antigéniques. Biochem. Biophys. Acta, $1955,17,67$.

13. Burtin, P., Application de la méthode d'Ouchterlony au systéme précipitant sérum albumine humaineimmunsérum de cheval. Bull. Soc. chim. biol., 1954, 36, 1021.

14. Wilson, M. W., and Pringle, B. H., Interpretation of the Ouchterlony precipitin test. J. Immunol., 1955, 75, 460.

15. Ouchterlony, O., Antigen-antibody reactions in gels. IV. Types of reactions in coordinated systems of diffusion. Acta path. et microbiol. Scandinav., 1953, 32, 231.

16. Oudin, J., Specific precipitation in gels and its application to immunochemical analysis in Methods in Medical Research. Chicago, Year Book Publishers, Inc., 1952, Vol. V, p. 335.

17. Ipsen, J., A standard for antistreptolysin-O of human serum, and its practical application. Acta path. et microbiol. Scandinav., 1944, 21, 203.

18. Fraser, D. T., and Wigham, H. E., The use of rabbits for intracutaneous virulence tests of B. diphtheriae or titration of diphtheria antitoxin. J. A. M. A., 1924, 82, 1114.

19. Holmberg, C. G., and Laurell, C.-B., Investigations in serum copper. II. Isolation of the copper containing protein, and a description of some of its properties. Acta chem. Scandinav., 1948, 2, 550.

20. Bloor, W. R., Pelkan, K. F., and Allen, D. M., Determination of fatty acids (and cholesterol) in small amounts of blood plasma. J. Biol. Chem., 1922, 52, 191.

21. Surgenor, D. M., Koechlin, B. A., and Strong, L. E., Chemical, clinical, and immunological studies on the products of human plasma fractionation. XXXVII. The metal-combining globulin of human plasma. J. Clin. Invest., 1949, 28, 73.

22. Koechlin, B. A., Preparation and properties of serum and plasma proteins. XXVIII. The beta -metal- $^{-}$ combining protein of human plasma. J. Am. Chem. Soc., 1952, 74, 2649.

23. Rutstein, D. D., Ingenito, E. F., and Reynolds, W. E., The determination of albumin in human blood plasma and serum. A method based on the interaction of albumin with an anionic dye-2-(4'hydroxy-benzeneazo) benzoic acid. J. Clin. Invest., 1954, 33, 211.

24. Edsall, J. T., Gilbert, G. A., and Scheraga, H. A., The non-clotting component of the human plasma fraction I-1 ("Cold insoluble globulin"). J. Am. Chem. Soc., 1955, 77, 157.

25. Armstrong, S. H., Jr., Budka, M. J. E., and Morrison, K. C., Preparation and properties of serum and plasma proteins. XI. Quantitative interpretation of electrophoretic Schlieren diagrams of normal human plasma proteins. J. Am. Chem. Soc., 1947, 69, 416.

26. Perlmann, G. E., Ropes, M. W., Kaufman, D., and Bauer, W., The electrophoretic patterns of proteins in synovial fluid and serum in rheumatoid arthritis. J. Clin. Invest., 1954, 33, 319.

27. Edsall, J. T., The size, shape and hydration of protein molecules in The Proteins. $\mathrm{H}$. Neurath and $\mathrm{K}$. Bailey, Eds., New York, Academic Press, Inc., 1953, Vol. I, part B, p. 549.

28. Noble, N. L., Boucek, R. J., and Kao, K. T., Lipoproteins of serum and connective tissue of rat and rabbit. Federation Proc., 1955, 14, 261.

29. Cohn, E. J., Gurd, F. R. N., Surgenor, D. M., Barnes, B. A., Brown, R. K., Derouaux, G., Gillespie, J. M., Kahnt, F. W., Lever, W. F., Liu, C. H., Mittelman, D., Mouton, R. F., Schmid, K., and Uroma, E., A system for the separation of the components of human blood: quantitative procedures for the separation of the protein components of human plasma. J. Am. Chem. Soc., 1950, 72, 465.

30. Pederson, K. O., The molecular weights of the proteins in Les protéines. Rapports et discussions. Neuvième conseil de chimie, Institut International de Chimie Solvay, Publiés par les Secrétaire du Conseil sous les auspices due Comité Scientifique de l'Institut. Bruxelles, R. Stoops, 1953, p. 19. 